\title{
ZAREBA, Slawomir H.; ZARZECKI, Marcin (Ed.). Between construction and deconstruction of the universes of meaning: research into the religiosity of academic youth in the years 1988-1998-2005-2017. Berlin: Peter Lang, 2020. ISBN 978-3631795170. 230 pp.
}

José Pereira Coutinho*

The studies on university students' religiosity are scarce. There are two major national studies on this topic. First: the US national survey 'Spirituality in Higher Education: Students' Search for Meaning and Purpose' (Astin et al., 2010). Second: the English national project 'Christianity and the University Experience in Contemporary England' (Guest et al., 2013). In European countries from Catholic tradition, all recent studies focus on specific regions or dioceses, not in a whole country: from Croatia (Boneta, 2016), Poland (Baniak, 2016; Szauer, 2018), and Portugal (Coutinho, 2011).

The project associated to this book fills a gap. Until now there were no national studies on academic youth religiosity from Catholic countries. The two national studies, mentioned before, did not focus on Catholicism, and the studies from Catholic European countries had limited regional scope. In addition, this project has a time-length of thirty years beginning just before the end of Polish Communism providing a great opportunity for exploring religious evolution. Other positive aspect of this project is the team, composed by fourteen Polish researchers, mainly sociologists, some of religion and/or youth, besides the coordinators, two professors of the Cardinal Stefan Wyszyński University (Warsaw), both sociologists of religion: one also sociologist of youth (Slawomir Zareba) and other also methodologist (Marcin Zarzecki). This project, with four rounds $(1988,1998,2005,2017)$, interviewed school and university students (but this book analyses only the university students) and used many variables from a few dimensions based mainly in Glock and Stark (1965). So, this study has everything to be good: novelty, time-length, and good team.

Probably the main strength of this book is the array of data, in quantity and diversity, as well as its diachronic nature. Yet, if data were organised differently and summarised, possibly the book would be sharper. To show this idea it is better to examine the book. First, the authors present the book, framing it theoretically and explaining the methodology of the project. Perhaps they could explore more both aspects. Then, they

* Doutor em Sociologia (ISCTE-IUL, Portugal). Membro integrado do CITER-UCP (Portugal). ORCID: 0000-0002-2733-3476 - Contato: jose.coutinho@numena.org.pt 


\section{$\mathbf{2 1 0} \mid$ José Pereira Coutinho}

divide the chapters in three parts, but they do not explain the reasons for that. The first part, with five chapters, relates to the consequential dimension, addressing attitudes towards the Decalogue, few aspects of sexuality, family, and life, and many values, as well as the role of religion in making one's life meaningful. Though, this part already denotes a problem. Since Glock and Start's dimensions were used, perhaps they could be more balanced: this first part could be smaller, and each part would be assigned to each dimension.

The second part, with seven chapters, is a motley of different dimensions and religious aspects. In the first two chapters, practices and beliefs are analysed. These two dimensions (ritualistic and ideological) have only one chapter for each which is strange since these are the two main dimensions in every study of religiosity. The other chapters analyse the supportive role of religion in everyday life, religious socialisation, attitudes towards the Catholic Church, the influence of religion on ethical profiles (which would be probably better in the first part), and the online searches for religion. While the community dimension (not used by Glock and Stark but by Fukuyama) is analysed in the fifth chapter, the experiential dimension is slightly analysed in the third chapter, and the intellectual dimension, though linked to ideological dimension, is not analysed. It is odd that they evoke Glock and Stark (and Fukuyama), but do not develop all their dimensions and, when they do, do not do it in a balanced way.

The third part analyses the non-religious aspects: social values linked to Poland or more politically oriented (first chapter), common interest versus own interest (second chapter), interests and grades (third chapter). This part makes sense since it gathers all non-religious aspects. To summarise and to interrelate so many data and information, the book could have a final chapter. This absence seems to reinforce a lack of coordination seen in the relevant differences between chapters: some chapters are deeper, other chapters are more superficial; some have more theory and explanations, others are more data-focused; some have conclusions or final remarks, others do not have them; some have plenty of bibliography, others are scarce of it; some cross variables with sociodemographic variables and religiosity, others do not do it. These asymmetries would be justified if each chapter was on different topics and/or used different data. Perhaps they puzzle the reader and show distinct levels of quality which may reduce book's value.

In sum, this is a valuable book, with diachronic and diversified data, about university students of a European country from Catholic tradition (Poland), which is novel, but it loses some strength due to a certain lack of coordination, balance, and summarisation. The lack of summarisation in the end makes it difficult to grasp the central idea and the main results of this study. Yet, the diachronic research of thirty years shows planning, commitment, and effort, which is very commendable and an example for all researchers.

\section{Bibliography}

ASTIN, Alexander W.; ASTIN, Helen S.; LINDHOLM, Jennifer A. Cultivating the spirit: how college can enhance students' inner lives. San Francisco, CA: JosseyBass, 2010. 
BANIAK, Josef. Religious and cultic activity of high school and university students in Poland: between religious zeal and lack of practice. Przegląd religioznawczy - The religious studies review, v. 262, n. 4, Warsaw, p.101-121, 2016.

BONETA, Željko. Klatno se i dalje njiše: institucionalna religioznost riječkih studenata. Sociologija i prostor, v. 54, n. 3, Zagreb, p.265-294, 2016.

COUTINHO, José P. Modernidade, religiosidade e universidade. 302f. Tese (doutoramento em sociologia), ISCTE-IUL, Lisboa, 2011.

GLOCK, Charles; STARK, Rodney. Religion and society in tension. Chicago, IL: Rand McNally and Company, 1965.

GUEST, Mathew; AUNE, Kristin; SHARMA, Sonya; WARNER, Rob.

Christianity and the university experience. London: Bloomsbury, 2013.

SZAUER, Remigiusz. Identyfikacja religijna młodzieży diecezji koszalińskokołobrzeskiej na podstawie analizy globalnego wyznania wiary. Uniwersyteckie czasopismo socjologiczne, v. 22, n. 1, Warsaw, p.47-57, 2018.

Editor: Silas Guerriero

Recebido em: 05/11/2021

Aprovado em: 12/11/2021 